\title{
A note using mergers and acquisitions to gain competitive advantage in the United States in the case of Latin American MNCs
}

\author{
Claudio D. Milman ${ }^{1}$ \\ Rollins College \\ James P. D’Mello \\ Western Michigan University \\ Bülent Aybar \\ Rochester Institute of Technology \\ Harvey Arbeláez \\ Monterey Institute of International Studies, \\ Fisher Graduate School of International Business
}

\footnotetext{
${ }^{1}$ In tribute to the memory of the late Claudio D. Milman, the order of the contributing authors has been reversed.

Citation: Milman, C. D., D’Mello, J. P., Aybar, B., \& Arbaláez, H. (2001). A note using mergers and acquisitions to gain competitive advantage in the United States in the case of Latin American MNCs. International Review of Financial Analysis, 10(3), 323-332. doi:10.1016/S1057-5219(01)00056-4
} 


\begin{abstract}
The "new" economic and business climate in Latin America, fostered by multilateral trade agreements such as NAFTA, MERCOSUR, and the ANDEAN Pact, suggests that Latin American (LA) firms must become more aggressive and competitive in order to survive.

Foreign direct investment in the form of mergers and acquisitions (M\&A) is often an effective way of competing in a tough global environment. Using transactions data collected from Security Data Company's Worldwide Merger and Acquisition database, this paper analyzes the relative involvement of firms from five LA countries (Argentina, Brazil, Chile, Mexico, and Venezuela) in acquiring targets in the United States of America. Transaction characteristics examined and summarized include the annual distribution (1985-1998) of the deals, the industrial sector of the target firm, the form of acquisition method used, and the form of ownership of the target firm. The trends are analyzed, and implications for managers are indicated.
\end{abstract}


"Mergers and acquisitions are a response to new technologies or market conditions which require a strategic change in a company's direction or use of resources." Michael C. Jensen (in His Own Words on Mergers and Acquisitions; emphasis added)

\section{Introduction}

After World War II, American companies dominated the international business scene. In the 1960s and 1970s, a new array of literature emerged concentrating on the increasing role and influence of Western European and Japanese multinational corporations. The acquisitive phenomenon (Haspeslagh \& Jemison, 1991), with deeper roots among American firms which, in their search for value have increased them from US\$186.4 billion in 1985 to US\$234.1 billion in 1989, has clear cross-border manifestations today in spite of their timid beginnings in Europe and Japan. For example, between 1985 and 1989, the European acquisition activity increased eight-fold to reach a level of US\$87.1 billion. However, in the same period, the number of acquisitions involving Japanese companies increased from 295 in 1985 to 660 in 1989. Of this total, only 15 were acquisitions by foreign companies in Japan. ${ }^{2}$ More importantly, cross-border mergers and acquisitions (M\&A) reached in 1999 another record of US\$720 billion. And as pointed out correctly in the 2000 World Investment Report, [although] "mergers and acquisitions take the lead, [I]t is not possible to determine precisely the share of cross-border M\&As in FDI inflows" (p. 13).

Dunning $(1981,1993)$ has shown how his "eclectic theory of international production" could be used to explain the outward direct investment of firms from developing countries. In order for foreign direct investment to take place, a firm must have three kinds of advantages:

(a) ownership-specific (to the extent that a firm has or can get tangible/intangible assets not available to competitors);

(b) internalization (to the extent that a firm is better off by using its ownership-specific advantages to internalize production); and

(c) location-specific (to extent that it would be profitable for a firm to open facilities in the countries under consideration).

\footnotetext{
2 For an evidence, see Yamaichi Securities Mergers and Acquisitions Strategy Group, and
} Amdata/Acquisitions Monthly Database. 
According to Dunning (1993), the ownership-specific advantages (the "why" of multinational activity), internalization-incentives advantages (the "how" of involvement), and location-specific advantages (the "where" of production) that are used to explain the behavior of traditional multinationals are applicable to third world multinationals.

From another perspective, it is also possible to argue that if firms of developing countries find difficulties in sharpening competitive advantages in their home markets in line with the prescriptions of the "diamond of national advantage" (Porter, 1990), the envisioned competitiveness can be found elsewhere. The diamond has four components:

(a) factor conditions (i.e., the existence of appropriate factors of production);

(b) demand conditions (i.e., the presence of sophisticated and demanding customers);

(c) related and supporting industries (i.e., the existence of a critical mass of related industries and suppliers);

(d) firm strategy, structure, and rivalry (i.e., the sufficiency of an organizational arrangement as well as the pressure imposed by the presence of competitors).

Clearly, when the home market conditions to build up competitiveness neither predominate nor promote it, and the firm aims at creating value, it may either search for an inward investment leading to a strategic alliance, joint-venture, merger and acquisition in the home market, or initiate an outward investment leading, for example, to a merger and acquisition in the foreign market.

On the other hand, it is interesting to note that as a result of the so-called "Washington Consensus," a "new" economic second business climate has been induced in Latin America. In June of 1990, former President Bush announced the Initiative of the Americas. This initiative has three major objectives:

(a) the eventual creation of a free trade area for the whole Western Hemisphere;

(b) the promotion of the private sector in Latin America; and

(c) the forgiveness of official debt owed by Latin American (LA) countries to the United States government. 
A note using mergers and acquisitions to gain competitive advantage 5

The Summit of the Americas that took place in Miami in December, 1994, reinforced the idea of the creation of a free trade area for the Western Hemisphere by the year 2005. All of these developments suggest that LA firms will have to become more aggressive, creative, and competitive in order to survive. As a result, one of the strategic responses of LA firms has been to seek benefits by means of initiating a process of doing business abroad through new entry methods such as foreign direct investment, joint ventures, and M\&A, in sharp contrast to the traditional approach of relying exclusively on exports. Indeed, there are no doubts that several LA firms are committed to the full internationalization of their operations (Gomez, 1997; Peres-Nunez, 1993).

Although a number of authors have analyzed the emergence of global competitors from developing countries (Aggarwal \& Agmon, 1990; Wells, 1983), the phenomenon of M\&A in the case of firms in developing countries, not as target firms but as acquiring ones, has not been yet explicitly recognized. For example, a recent study (De Castro \& Uhlenbruck, 1997), on acquiring and target firms by country groups, drawn from the Investment Dealers' Digest (IDD) M\&A database, shows no activity in M\&A initiated in either former communist or developing countries.

The reality, however, is different, at least from the perspective of LA MNCs, as it is argued in this paper. Indeed, as reported in a very recent UNCTAD conference held in Bogota, Colombia, despite the fact that foreign investment in Latin America reached US\$56 billion in 1997, LA firms invested US\$9 billion outside the region (www.elcolombiano.com, 1998). More importantly, these LA firms have mainly chosen firms in the United States as their target firms, which corroborates, to some extend, the prescriptions of the international product life cycle theory of foreign investment. In effect, if firms from developing countries do not take the initiative to invest abroad, particularly in the developed world through M\&A, then the expected may be a reality, as the Prime Minister Mahathir of Malaysia phrased it in his address to UNCTAD X in February 2000:

...mergers and acquisitions...are making big corporations even bigger. Now many of these corporations are financially more powerful than medium sized countries. While we welcome their collaboration with our local companies, we fear that if they are allowed into our countries unconditionally they may swallow up all our businesses. (United Nations, 2000, p. 6) 
A note using mergers and acquisitions to gain competitive advantage 6

The purpose of this paper is to analyze the use of M\&A by LA firms to enter the US market. The first part of the paper discusses the data sources used, important characteristics of M\&A transactions, and reasons why they are of importance to managers of multinational corporations and international investors. Part 2 discusses the results, and Part 3 makes some concluding comments.

\section{Data source and characteristics examined}

Data for this study were collected from the Security Data Company's (SDC's) Worldwide M\&A database, which is considered to be one of the most comprehensive sources of M\&A data. This database contains information on M\&A transactions where the value of the transaction exceeded US\$1 million (all transactions are included after 1992), the value is undisclosed (that is, the target is privately held or a subsidiary), or if the purchase resulted in $5 \%$ or more ownership of the target.

Besides the annual distribution of M\&A deals involving American targets and LA acquirers, during the January 1985 through June 1998 period, four characteristics of M\&A transactions are examined. The characteristics are: the industrial sector of the target firm, the type of acquisition, the home country of the acquiring firm, and the form of ownership of the target firm. The description of and rationale for these characteristics is provided below.

\subsection{Industrial sector of the target firm}

Through M\&A, companies are often able to extend market reach or product range (Subramanian, Ebrahimi, \& Thibodeaux, 1992). Knowledge of the industrial sector of firms being acquired by LA firms in the US gives managers an idea of the types of opportunities available for investment through M\&A. It also provides information of the relative niche that firms from certain countries have been able to carve for themselves. Certain industries may be heavily regulated or not available for sale to foreign buyers. Managers looking to invest in these industries in the US may have to look to other ways of executing the investment such as through joint ventures, strategic alliances, or through building new facilities. In this paper, targets are classified as being in: manufacturing, services, wholesale and retail trade, the financial sector, or natural resources, as defined and categorized by SDC. 
A note using mergers and acquisitions to gain competitive advantage 7

\subsection{Type of transaction}

M\&A transactions fall into three basic categories (1) asset acquisitions, (2) mergers, and (3) stock acquisitions. Each of these transactions has different consequences with respect to legal obligations, acquisition procedures, and tax liabilities (Marren, 1993). Knowledge of the types of transactions that normally occur in a nation and within a particular industrial sector gives managers a better idea of what to be prepared for when contemplating a M\&A transaction.

In an asset acquisition, an acquiring company purchases part or all of the assets of the target. The acquiring company purchases only the assets it desires and does not have to take on all of the target's liabilities. The target remains legally in existence after the transaction, although it may be liquidated after a major asset sale to return money to the shareholders. The transaction is normally executed by the management of both the target and the acquiring firm. If the transaction is particularly large, it may have to be voted on by the firm's board of directors or stockholders.

In a merger transaction, the target company is dissolved into the acquiring company. The target company ceases to exist as a separate entity. The transaction can be executed through an exchange of stock or assets. The procedures for executing a merger transaction tend to be fairly straightforward (Marren, 1993). On the downside, mergers often require the approval of both the acquiring and target firms' shareholders, and the acquiring firm assumes all of the target's liabilities.

A stock acquisition occurs when the acquiring company buys shares in the target company from individual stockholders. If the stock is privately held, the acquirer can deal with the stockholders individually. If the target is a wholly owned subsidiary of another company, the transaction is conducted by the management of the acquiring firm and the target's parent. If the stock of the target is publicly held, the acquiring firm may have to deal with a large group of disorganized shareholders. In these instances, a tender offer is usually announced for the outstanding shares. While a tender offer is a transaction that is conducted between the acquiring firm and the target firm's shareholders, the acquiring firms normally negotiates the transaction with the target's board of directors and managers.

An advantage of stock acquisitions is that they tend to be easy to execute and can be accomplished quickly (Marren, 1993). The transaction involves an exchange of stock 
certificates for payment. An acquirer can also secure partial ownership in a company through a stock acquisition. One of the problems with stock deals is that the acquiring company assumes all liabilities of the target and the deal can be resisted by a firm's management and/or board of directors. The SDC database allows us to identify M\&A transactions as (1) asset acquisitions, (2) mergers or 100\% stock acquisitions, (3) buybacks, and (4) stock acquisitions for partial, majority or remaining interest in a target.

\subsection{Home country of the acquiring firm}

International or cross-border M\&As have been a popular strategic tool for multinational firms looking to extend their market reach, develop new manufacturing facilities, develop new sources of raw materials, and tap into capital markets (Weston, Chung, \& Hoag, 1990). Cross-border deals have been numerous and large during the 1990s (Subramanian et al., 1992), and are expected to reach new heights due to international privatization trends, reduction in cumbersome industry regulations and red tape, and development of uniform accounting standards by many capital-starved nations (Zuckerman, 1993). Furthermore, as regional economic agreements continue to emerge, cross-border deals will continue to rise.

This paper examines the incidence of cross-border acquisitions of US firms by firms from five major emerging countries in Latin America, i.e., Argentina, Brazil, Chile, Mexico, and Venezuela. The frequency and total disclosed value of the M\&A are compared. Knowledge of the cross-border transactions that have taken place between US targets and LA acquirers gives an idea of the opportunities that are being capitalized on by companies from the emerging markets of Latin America. It also gives companies an indication of where competition for American assets is likely to come from and of the comparative and competitive advantage of LA firms.

\subsection{Ownership of the target firm}

The form of ownership of a target can also effect the acquisition process. Targets can be publicly owned, privately held (either by individual shareholders or by a parent company), subsidiaries of a parent company, a joint venture, or government-owned. Acquisitions of publicly owned companies can be made through transactions negotiated with management or 
through direct appeals to outside shareholders. Firms wishing to acquire privately held companies will need to negotiate the transaction with the firm's managers and/or owners (who also may be the firm's managers).

Companies wishing to purchase a subsidiary of a company will typically have to negotiate with the managers of the parent firm. If the target is a joint venture, the acquiring company will have to deal with two or more parent firms. Purchases of government-owned targets normally entail a careful bidding process (Brown \& Ridley, 1994).

\section{Results}

According to SDC, between January 1, 1985 and June 30, 1998, 67 M\&A deals had been completed involving US targets and LA acquirers. Of these 67 deals, 48 deals had a combined disclosed value of US\$7.04 billion and the remaining 19 deals had no disclosed values. Although Argentina accounted for the second lowest number of deals (3), an Argentinian acquirer (YPF SA) was responsible for the largest deal, valued at US\$1.84 billion. Chile accounted for only one deal valued at US\$534 million. Brazilian firms were involved in 11 deals, 7 of which had a combined disclosed value of US\$78.2 million. Venezuelan firms also accounted for 11 deals with a combined disclosed value of US\$1.1 billion (7 deals). As expected, of the various LA firms, Mexico has been responsible for the largest number of M\&A deals in the US. In all, 41 deals were completed by Mexican acquirers, with 31 deals having a combined disclosed value of US\$3.45 billion. Of the 48 M\&A deals by LA acquirers, which had a disclosed value, 69\% (33 deals) were valued at less than US\$100 million. Thus, with a few exceptions, most of the deals completed by LA firms in the US tend to be fairly low in value.

Table 1

Distribution of M\&A deals involving US targets and LA acquirers based on target's industry group

\begin{tabular}{lcccccr}
\hline & \multicolumn{2}{c}{ Industry group of target firm } & & & \\
\cline { 2 - 7 } Acquiring firm's nation & Manufacturing & Services & Trade & Financial & Natural Resources & Total \\
\hline Argentina & 0 & 1 & 0 & 0 & 2 & 3 \\
Brazil & 6 & 1 & 2 & 0 & 2 & 11 \\
Chile & 0 & 0 & 1 & 0 & 0 & 1 \\
Mexico & 23 & 6 & 6 & 1 & 5 & 41 \\
Venezuela & 2 & 1 & 2 & 0 & 6 & 11 \\
Total & 31 & 9 & 11 & 1 & 15 & 67 \\
\hline
\end{tabular}


Prior to 1989, only four deals are reported in the SDC database. Beginning in 1989, the number of deals has increased progressively each year. In 1997, seven deals were completed, and the trend was continuing in 1998 with eight deals already completed by midyear. This relative increase in direct investment by LA firms into the US is probably an expected outcome of the multilateral trade agreements such as NAFTFA, MERCOSUR, ANDEAN Pact, etc. that have been reached during the 1990s.

Table 1 shows the distribution of the M\&A deals completed by LA acquirers based on the industrial sector of the target firm. The manufacturing sector accounted for the most deals (31 out of 67), followed by the natural resources sector (15 deals). Within the manufacturing sector, Mexico accounted for the vast majority of the deals (23 out of 31), followed by Brazil (6). Venezuelan firms (six deals) were the main acquirers within the natural resources sector. This analysis shows that either LA firms have been relatively less interested in acquiring firms in the services, trade, and financial sectors within the US, or that they lack the competitive advantage in these sectors. Perhaps the corporate sector in the LA nations should explore possibilities of setting up strategic alliances and developing competitive strength in these sectors.

Table 2 organizes the M\&A deals completed by LA firms in the US on the basis of the type of acquisition method used by the acquiring firm, i.e., asset acquisition, stock acquisition, or merger. Thirty-one out of the 67 deals (46\%) involved the acquisition of assets of the target firm. Stock acquisitions accounted for 27 of the deals and only nine deals were Table 2 Distribution of M\&A deals involving US targets and LA acquirers based on acquisition method

\begin{tabular}{lccccr}
\hline & \multicolumn{3}{c}{ Acquisition Method } & & \\
\cline { 2 - 5 } Acquiring firm's nation & Mergers & $\begin{array}{l}\text { Acquition } \\
\text { of remaining } \\
\text { interest }\end{array}$ & $\begin{array}{l}\text { Acquisition } \\
\text { of partial } \\
\text { interest }\end{array}$ & $\begin{array}{l}\text { Acquisition } \\
\text { of assets }\end{array}$ & Total \\
\hline Argentina & 1 & 0 & 0 & 1 & 3 \\
Brazil & 0 & 1 & 0 & 7 & 11 \\
Chile & 0 & 0 & 0 & 1 & 1 \\
Mexico & 8 & 0 & 5 & 19 & 41 \\
Venezuela & 0 & 1 & 5 & 3 & 11 \\
Total & 9 & 2 & 10 & 31 & 67 \\
\hline
\end{tabular}


Table 3

Distribution of M\&A deals involving US targets and LA acquirers based on target's ownership status

\begin{tabular}{lccccr}
\hline & & & \multicolumn{2}{c}{ Acquisition Method } & \\
\cline { 3 - 6 } Acquiring firm's nation & Public & Private & Subsidiary & Joint venture & Total \\
\hline Argentina & 2 & 0 & 1 & 0 & 3 \\
Brazil & 2 & 5 & 4 & 0 & 11 \\
Chile & 0 & 1 & 0 & 0 & 1 \\
Mexico & 13 & 9 & 19 & 0 & 41 \\
Venezuela & 2 & 2 & 6 & 1 & 11 \\
Total & 19 & 17 & 30 & 1 & 67 \\
\hline
\end{tabular}

done using mergers. This shows that LA firms have preferred to enter into the US by directly acquiring American assets.

In Table 3, we present a breakdown of the M\&A deals based on the ownership status of the target firm. Overall, US targets have tended to be subsidiaries of other companies (30/67 or $45 \%$ of all targets), followed by publicly owned companies (19/67 or $28 \%$ ), and privately held firms (17/67 or 25\%). Only one of the M\&A deals involved a joint venture.

We were interested to know whether there were any specific patterns of acquisition method and ownership status within each industry group. We therefore sorted the data on the basis of the industry group, then by form of acquisition, and ownership status. Within the manufacturing sector, there was a preference for asset acquisitions (14 out of 31), followed by acquisition of partial interest (9) and mergers (5). Furthermore, out of the nine mergers that were completed, six were done in the manufacturing sector. As far as ownership status is concerned, 22 of the targets were mainly publicly owned or subsidiaries. Very few private manufacturing firms were acquired (only 9 out of 31 ).

Within the natural resources sector, we found that LA firms prefer to use asset acquisitions (6/15) and acquisition of majority interest (4/15). Furthermore, 11 out of 15 US targets in the natural resources sector were subsidiaries. Within the trade sector, 9 out of 11 deals were completed using asset acquisitions.

\section{Conclusions}

After analyzing the data, we find that since 1989 LA firms have become more active players in the US market. Of the five countries that we included in our study, Mexico has 
dominated the scene in the manufacturing sector, while Venezuela has been very competitive in the natural resources (petrochemical) sector. Surprisingly, Chile, which has demonstrated tremendous economic and political stability since 1985, has not played a major role in this market. Perhaps, these trends are due to the geographical proximity of Mexico and Venezuela to the US, and the signing of the North-American Free Trade agreement of Mexico with the US and Canada, and the membership of Venezuela to the Group of Three that includes also Mexico and Colombia.

The sectors that have been targeted, namely, light manufacturing (pottery and chemical products) and natural resources (petroleum refineries) are indicative of the use of comparative advantage by LA firms in their own foreign direct investments in the United States. However, the activity has been relatively light. There is clearly a need for more activity in these sectors and managers of LA MNCs, especially from Chile, Brazil, and Argentina, should be looking towards the US for opportunities whereby they can use their comparative advantage in managing companies more efficiently.

A final conclusion refers to the contribution of this paper to the literature on M\&A. The paper focuses on the emergence of LA MNCs as beginning players in a phenomenon, which has been considered almost exclusive to the developed world. Moreover, M\&A activities initiated abroad by LA firms may reflect also a trend in the same activities carried out only at the interior of their respective countries. Such a phenomenon may represent, however, an area of further research as well because alike strategic alliances, international M\&A, "all face similar challenges: they must value the target enterprise on the basis of its projected performance in its market" (Eiteman, Stonehill, \& Moffett, 2001, p. 449).

\section{References}

Aggarwal, R., \& Agmon, T. (1990). The international success of developing country firms: role of government directed comparative advantage. Management International Review, 30 (2), 163-180.

Brown, M., \& Ridley, G. (1994). Privatization-current issues. London, UK: Graham and Trotman.

De Castro, J. O., \& Uhlenbruck, K. (1997). Characteristics of privatization: evidence from developed, less-developed, and former communist countries. Journal of International Business Studies, 28 (1), 123-143. (First Quarter).

Dunning, J. (1981). Exploring the international direct investment position of countries: toward a dynamic or developmental approach. Weltwirtschaftliches, 117 (1), 30-64. 
Dunning, J. (1993). Multinational enterprises and the global economy. Reading, MA: Addison-Wesley Publishing.

Eiteman, D. K., Stonehill, A. I., \& Moffett, M. H. (2001). Multinational business finance (9th ed.). Reading, MA: Addison-Wesley Publishing.

Gomez, H. (1997). The globalization of business in Latin America. International Executive, 39 (2), 225-254. (March/April).

Haspeslagh, P. C., \& Jemison, D. B. (1991). Managing acquisitions: creating value through corporate renewal. New York, NY: Free Press.

Marren, J. H. (1993). Mergers and acquisitions: a valuation handbook. Homewood, IL: Business One Irwin.

Peres-Nunez, W. (1993). The internationalization of Latin American industrial firms. CEPAL Review, 49, 55-74. (April).

Porter, M. (1990). The competitive advantage of nations. London, UK: Macmillan Press.

Subramanian, R., Ebrahimi, B., \& Thibodeaux, M. (1992). Research on merger performance: a review and critique. International Journal of Commerce and Management, 1, 4-16.

United Nations. (2000). World investment report on cross-border mergers and acquisitions and development. Geneva, Switzerland: United Nations.

Wells, L. T. (1983). Third worm multinational: the rise of foreign investment from developing countries. Cambridge, MA: MIT Press.

Weston, F., Chung, K., \& Hoag, S. (1990). Mergers, restructuring and corporate control. Englewood Cliffs, NJ: Prentice-Hall.

www.elcolombiano.com, 1998. Colombia, Polo de Inversion Extranjera (Tuesday, November 10).

Zuckerman, G. (1993). For international M\&A, an untraditional year. Investment Dealers' Digest, 59 (3), 21-24. (January 18). 